Gut, 1969, 10, 334-335

\title{
Bacteria and the aetiology of cancer of the large bowel
}

\author{
VIVIENNE ARIES, J. S. CROWTHER, B. S. DRASAR, M. J. HILL, AND \\ R. E. O. WILLIAMS \\ From the Bacteriology Department, Wright-Fleming Institute, St Mary's Hospital Medical School, \\ London
}

Cancer of the large bowel shows marked variations in geographical distribution (Doll, 1967; Doll, Payne, and Waterhouse, 1966; Davis, Knowelden, and Wilson, 1965) and, with the exception of Japan, the disease is more prevalent in developed than in underdeveloped countries. The reason for this variation is not known but epidemiological evidence suggests that environmental factors may be involved. It is claimed that immigrants from areas with a low incidence of cancer of the large bowel tend to show the same high incidence of this cancer as the local population (Haenszel and Dawson, 1965; Buell and Dunn, 1965). Changes in dietary habit may be especially important (Wynder and Shigematsu, 1967; Buell and Dunn, 1965) and diet is known to affect the nature and distribution of bacteria in the faeces (Hoffmann, 1964; Dubos, 1965).

Among the important metabolic activities of intestinal bacteria is the degradation of bile salts (Hill and Drasar, 1968). It seems possible that some of the bacteria in the bowel could convert bile salts, or steroids in the diet, into carcinogens; Haddow (1958) has reviewed the ways in which it is possible, in the laboratory, to convert deoxycholate into 20-methylcholanthrene, a potent carcinogen.

We have, therefore, compared the bacterial flora of the faeces from people in England, an area with a high incidence of cancer of the large bowel, with that from people in Uganda, where the incidence is low. We have also compared the abilities of English and Ugandan strains of faecal bacteria to degrade bile salts and have examined the products of bile degradation in English and Ugandan faeces.

\section{MATERIALS AND METHODS}

Samples of freshly voided faeces from $\mathbf{4 8}$ healthy Ugandan adults living in and around Kampala and from $\mathbf{4 0}$ healthy English adults living in London were examined. Specimens were preserved for transport and storage as a $10 \%$ suspension in meat infusion broth containing $10 \%$ glycerol frozen on solid carbon dioxide (Drasar, Shiner, and McLeod, 1969); the bacteria have been found to survive well under these conditions. Specimens were cultivated by the methods described previously (Drasar, 1967) with minor modifications. Approximately equal numbers of English and Ugandan specimens were examined on each day of testing in order to compensate for minor fluctuations in culture media, incubation temperatures, and operational techniques.

Methods for investigating the degradation of bile salts are described elsewhere (Hill and Drasar, 1968; Aries, Crowther, Drasar, and Hill, 1969).

\section{RESULTS AND DISCUSSION}

Our findings are summarized in the Table. The same

TABLE

BACTERIAL COUNTS OF FAECES FROM 40 ENGLISH AND 48 UGANDAN ADULTS ${ }^{1}$

\begin{tabular}{lllc} 
Organism & English & Ugandan & $\mathbf{P}^{2}$ \\
\hline Bacteroides & $9.7 \pm 0.6$ & $\mathbf{8 . 2} \pm 1.1$ & $<0.001$ \\
Bifidobacteria & $9.9 \pm 0.3$ & $9.3 \pm 0.6$ & $<0.001$ \\
Aerobic streptococci & $7.0 \pm 0.8$ & $7.8 \pm 0.9$ & 0.01 \\
Enterococci & $5.7 \pm 1.3$ & $7.0 \pm 1.2$ & 0.01 \\
Lactobacilli & $6.0 \pm 1.6$ & $7.2 \pm 1.1$ & 0.01 \\
Yeasts & $1.3 \pm 1.8$ & $3.1 \pm 2.0$ & 0.01 \\
Enterobacteria & $7.5 \pm 1.2$ & $\mathbf{8 . 0} \pm 0.8$ & $>0.05$ \\
Clostridia & $4.4 \pm 1.8$ & $\mathbf{4 . 0} \pm 1.9$ & $>0.05$ \\
Veillonellae & $4.4 \pm 2.1$ & $5.3 \pm 1.4$ & $>0.05$ \\
Filamentous fungi & $1.4 \pm 1.2$ & $2.2 \pm 1.2$ & $>0.05^{3}$
\end{tabular}

${ }^{1}$ Arithmetic mean of $\log _{10}$ organisms per $\mathrm{g}$ wet weight \pm standard error.

${ }^{2}$ Agreed values obtained from both the student $t$ test and the $x^{2}$ test. ${ }^{8}$ Agreed value obtained from both a rank test and the $\chi^{2}$ test.

groups of bacteria occurred in both populations but there were significant quantitative differences. Although the dominant bacteria in both populations were non-sporing anaerobes (bacteroides and bifidobacteria), the English specimens contained 30 times more bacteroides than did the Ugandan. Streptococci, enterococci, lactobacilli, and yeasts occurred in significantly greater numbers in the Ugandan specimens. No significant differences were 
found in the numbers of clostridia, enterobacteria, veillonellae, or filamentous fungi.

The observed differences in the faecal flora of the two populations may be attributable to the radical differences in the diets. The English people we studied lived on diets containing mixed animal and vegetable foods. The Ugandans lived on a high carbohydrate vegetarian diet containing very little fat and almost no animal protein.

As reported elsewhere (Aries et al, 1969), English and Ugandan strains of the same group of bacteria were equally active in degrading bile salts, the bacteroides and clostridia being by far the most active in both deconjugation and further degradation of bile salts. Preliminary results, however, indicate that the bile salts present in English faeces are much more degraded than those in Ugandan and this presumably reflects the much higher numbers of bacteroides; clostridia, though equally active and equally prevalent in both populations, are present in much smaller numbers. The more degraded bile salts are presumably more likely to be converted into carcinogens.

The results presented here are compatible with the hypothesis that differences in the bacterial flora of the bowel, by leading to different degrees of degradation of bile salts, might be one cause of the varying geographical incidence of carcinoma of the large bowel. We hope to extend this survey to study the faeces of other populations with a high or low incidence of large bowel cancer.

SUMMARY

In a study designed to discover whether the frequency of large bowel cancer could be related to the bacterial flora of the bowel, the faeces of healthy English and Ugandan adults were compared bacteriologically. The faeces from the English subjects contained significantly more bacteroides and bifidobacteria but fewer streptococci and lactobacilli than those from the Ugandans. Bacteroides are very active in the degradation of bile salts and it is suggested that they might produce carcinogens.

We thank Professor R. Blowers at Makerere University College, Kampala, Uganda, and the director and nursing staff of the Medical Research Council Child Nutrition Unit, Kampala, for their invaluable work in obtaining the Ugandan faeces for us. Dr W. R. S. Doll of the Statistical Research Unit, University College Hospital Medical School, London, and Dr F. Avery Jones and Dr E. N. Rowlands of the Medical Research Council Gastroenterology Research Unit, Central Middlesex Hospital, London, all gave valuable help and advice.

We also acknowledge the very capable technical assistance of Miss R. Scutt and Miss R. Steward. The project was supported by grants from the British Empire Cancer Campaign (V.C.A., J.S.C., M.J.H.) and the Medical Research Council (B.S.D.).

\section{REFERENCES}

Aries, V. C., Crowther, J. S., Drasar, B. S., and Hill, M. J. (1969). Degradation of bile salts by human intestinal bacteria. Gut, in press.

Buell, P., and Dunn, J. E., Jr (1965). Cancer mortality among Japanese Issei and Nisei of California. Cancer, 18, 656-664.

Crowther, J. S., and Drasar, B. S. In preparation.

Davis, J. N. P., Knowelden, J., and Wilson, B. A. (1965). Incidence rates of cancer in Kyadondo County, Uganda 1954-1960. J. nat. Cancer Inst., 35, 789-821.

Doll, R., Payne, P., and Waterhouse, J. (Editor). (1966). Cancer Incidence in Five Continents: A Technical Report. International Union Against Cancer, Springer, Berlin.

- (1967). World wide distribution of gastrointestinal cancer. Nat. Cancer Inst. Monogr., 25, 173-190.

Drasar, B. S. (1967). Cultivation of anaerobic intestinal bacteria. J. Path. Bact., 94, 417-427.

- Shiner, M., and McLeod, G. M. (1969). Studies on the intestinal flora. I. The bacterial flora of the gastrointestinal tract of healthy and achlorhydric persons. Gastroenterology, 56, 71-79.

Dubos, R. (1965). Man Adapting. Yale University Press, New Haven.

Haddow, A. (1958). Chemical carcinogens and their modes of action. Brit. med. Bull., 14, 79-92.

Haenszel, W., and Dawson, E. A. (1965). A note on mortality from cancer of the colon and rectum in the United States. Cancer, 18, 265-272.

Hill, M. J., and Drasar, B. S. (1968). Degradation of bile salts by human intestinal bacteria. Gut, 9, 22-27.

Hoffmann, K. (1964). Untersuchungen über die Zusammensetzung der Stuhlflora während eines langauernden Ernährungsversuches mit kohlenhydratreicher, mit fettreicher und mit eiweissreicher Kost. Zbl. Bakt. (I. Abt., Orig.), 192, 500-508.

Wynder, E. L., and Shigematsu, T. (1967). Environmental factors of cancer of the colon and rectum. Cancer, 20, 1520-1561. 